\title{
Hubungan Kemampuan Motorik Terhadap Hasil Belajar Pendidikan Jasmani Olahraga Dan Kesehatan Siswa Kelas V Putra Sekolah Dasar Negeri 25 Air Tawar Selatan
}

\author{
Osmil1a $^{1}$, Rosmawati $^{2}$, Ruri Famelia ${ }^{3}$ \\ ${ }^{123}$ Fakultas Ilmu Keolahragaan, Universitas Negeri Padang, Indonesia.
}

E-mail: osmila@gmail.com¹ ${ }^{1}, \underline{\text { rosmawati@,fik.unp.ac.id }{ }^{2}, \text { rurifamelia@,fik.unp.ac.id }}$

\begin{abstract}
Abstrak
Masalah dalam penelitian ini adalah rendahnya hasil belajar siswa dalam mata pelajaran Pendidikan Jasmani Olahraga dan Kesehatan. Belum di ketahui masalah pasti apa yang menyebabkan rendahnya hasil belajar siswa. Banyak faktor-faktor penyebab yang memungkinkan rendahnya hasil belajar baik yang bersifat internal maupun eksternal. Adapun yang berfokus dalam penelitian ini tidak yang berkaitan dengan kemampuan motorik. Penulis ingin melihat apakah terdapat hubungan kemampuan motorik dengan hasil belajar . dengan demikian tujuan penelitian ini adalah untuk melihat hubungan kemampuan motorik dengan hasil belajar.

Jenis penelitian ini adalah penelitian korelasional yaitu suatu penelitian yang menetukan tingkat hubungan antara variabel bebas dengan variabel terikat. Adapun hubungan yang akan diteliti adalah variabel bebasnya kemampuan motorik dengan variabel terikatnya adalah hasil belajar siswa Sekolah Dasar Negeri 25 Air Tawar Selatan Kecamatan Padang Utara Kota Padang. Populasi dalam penelitian adalah seluruh siswa Sekolah Dasar Negeri 25 Air Tawar Selatan Kecamatan Padang Utara Kota Padang yang terdaftar pada tahun ajaran 2010/2011 yang berjumlah 132 orang siswa yang terdiri dari 78 orang laki-laki dan 58 orang perempuan mulai dari kelas I sampai kelas VI dan mengingat keterbatasan waktu, tenaga, biaya, serta kemampauan yang dimiliki, maka penelitian ini tidak dilakukan terhadap semua populasi. Adapun yang menjadi sampel dalam penelitian ini yaitu kelas $\mathrm{V}$ (lima) putra saja yang berjumlah 20 diambil berdasarkan total random sampling.

Dengan melihat tabel distribusi $\mathrm{t}$ dengan $\mathrm{dk}=\mathrm{n}-23$, diperoleh nilai tabel 1.72 , yaitu dari $1-\alpha$ atau 0.95 sebagai dk pembilang dan $\mathrm{n}-2$ (21) sebagai dk penyebut. Kriteria pengujian adalah jika $t_{\text {hitung }}>\mathrm{t}_{\text {tabel }}, \mathrm{H}_{\mathrm{o}}$ yang menyatakan tidak terdapat hubungan antara table yang di tolak. Sebaliknya jika $t_{\text {hitung }}<t_{\text {tabel }}$ Ho diterima. Oleh karena itu $t_{\text {hitung }}(4,835)>t_{\text {tabel }}(1.72)$ maka Ho di tolak dan Ha diterima, dengan demikain dapat disimpulkan bahwa terdapat hubungan yang signifikan antara variable bebas dengan variable terikat. Dengan kata lain terdapat hubungan yang berarti antara Kemampuan Motorik dengan Hasil belajar Pendidikan Jasmani Olahraga dan Kesehatan.
\end{abstract}

Kata Kunci: Kemampuan Motorik, Hasil Belajar, Pendidikan Jasmani Olahraga, Pendidikan Kesehatan

Abstract

The problem in this study is the low student learning outcomes in Sports Physical and Health Education subjects. The exact problem is not yet known what causes the low student learning outcomes. Many factors cause the low learning outcomes both internal and external. As for who focuses in this study is not related to motor skills. The author wants to see whether there is a relationship between motor skills and learning outcomes. thus the purpose of this study is to look at the relationship between motor skills and learning outcomes.

This type of research is a correlational study that is a study that determines the level of relationship between the independent variable with the dependent variable. The relationship to be 
investigated is the independent variable motor ability with the dependent variable is the learning outcomes of 25 Air Tawar Selatan Elementary School students in Padang Utara District, Padang City. The population in this study were all students of 25 Air Tawar Selatan Elementary School, Padang Utara District, Padang City registered in the 2010/2011 school year, totaling 132 students consisting of 78 men and 58 women ranging from grade I to grade VI and considering the limitations of time, energy, cost, and ability possessed, this study was not conducted on all populations. As for the sample in this study is class $V$ (five) only 20 sons taken based on total random sampling.

By looking at the distribution table $t$ with $d k=n-23$, a value of ttable 1.72 is obtained, namely from $1-\alpha$ or 0.95 as the numerator $d k$ and $n-2$ (21) as the denominator $d k$. The test criterion is if tcount $>$ ttable, Ho which states there is no relationship between the rejected table. Conversely, if tcount $<$ t table $\neg$ Ho is accepted. Therefore tcount $(4,835)>$ ttable (1.72) then Ho is rejected and Ha is accepted, thus it can be concluded that there is a significant relationship between the independent variable and the dependent variable. In other words there is a significant relationship between motor skills with physical and physical education learning outcomes.

\section{Keywords: Motor Ability, Learning Outcomes, Physical Education, Sports, Health Education}

\section{PENDAHULUAN}

Kemampuan motorik adalah kemampuan gerak dasar atau kualitas hasil gerak yang berasal dari dalam maupun luar diri anak untuk mengacu pada keterampilan gerak rendah yang dapat ditingkatkan melalui latihan dan merupakan perubahan gerak dasar dari semenjak bayi hingga dewasa yang melibatkan beberapa komponen-komponen gerak dalam melakukan suatu aktivitas gerak olahraga maupun aktivitas gerak olahraga maupun aktivitas gerak sehari-hari.

Seseorang yang memiliki kemampuan motorik yang tinggi diduga akan lebih baik dan berhasil dalam melakukan berbagai tugas keterampilan, dibandingkan dengan seseorang yang memiliki kemampuan motorik rendah. Kemampuan motorik yang dimiliki seseorang berbeda-beda dan tergantung kepada banyaknya pengalaman gerakan yang dikuasai. Prinsip kemampuan motorik anak satu perubahan, baik fisik mau psikis, sesusai dengan masa pertumbuhan dan masa perkembangannya.

Sekolah Dasar Negeri 25 Air Tawar Padang merupakan salah satu lembaga pendidikan dasar yang bergerak dalam berbagai bidang dasar keilmuan di antaranya olahraga dan kesehatan, sekolah ini selalu tanggap dengan perkembangan dunia olahraga dan pendidikan jasmani. Berbagai aktivitas jasmani dan olahraga diberikan kepada siswa dalam mata pelajaran pendidikan jasmani olahraga dan kesehatan dimaksud yaitu: permainan dan olahraga, aktivitas pengembangan diri, aktivitas senam, aktivitas ritmik, aktivitas di air, pendidikan luar sekolah, serta kesehatan. Dengan demikian jelas bahwa siswa yang telah mengukuti mata pelajaran pendidikan jasmani olahraga dan kesehatan dapat meningkatkan pengetahuan, keterampilan, serta kesegaran jasmaninya.

Pengembangan kesegaran jasmani dalam pendidikan diberikan sejak usia dini di bangku sekolah dasar melalui pendidik jasmani. Menurut Standar Kompetensi Mata Pelajaran pendidikan jasmani sekolah dasar, Pendidikan jasmani adalah proses pendidikan yang memanfaatkan aktivitas jasmani yang direncanakan secara sistematik yang bertujuan untuk meningkatkan individu secara organik, neuromuskuler, perseptual, kognitif, dan emosional (Depdiknas, 2003:1).

Berdasarkan pengamatan penulis sebagai guru mata pelajaran pendidikan jasmani olahraga dan kesehatan serta pembina kegiatan luar sekolah, penulis belum punya data yang akurat tentang kebugaran jasmani siswa, serta sejauh mana kontribusi mata pelajaran pendidikan jasmani olahraga dan kesehatan terhadap peningkatan kesegaran jasmani siswa pada Sekolah Dasar Negeri 25 Air Tawar Padang. Di samping itu berdasarkan pengamatan penulis terlihat anak malas bergerak, kurang bergairah waktu belajar, serta sering mengantuk. Berbagai aktivitas jasmani dan olah raga telah dilaksanakan pada sekolah dimaksud melalui mata pelajaran pendidikan jasmani olahraga dan 
kesehatan, namun juga sering timbul pertanyaan di berbagai kalangan guru, masyarakat, maupun insan olahraga, apakah mata pelajaran tersebut dapat meningkatkan kesegaran jasmani siswa.

Selanjutnya kemampuan motorik sangat penting dan merupakan kebutuhan yang harus dipelajari terutama pada usia sekolah dasar, karena hal ini dapat menunjang perkembangan gerak dan postur tubuh akan lebih baik jika dilaksanakan pada usia dini. Menurut Nugroho (2005:12) kinerja dalam keterampilan motorik kasar (gross motor skill) memiliki komponen-komponen sebagai berikut: “1) kekuatan otot, 2) daya tahan, 3) kecepatan, 4) kelincahan, 5) koordinasi. Komponen-komponen kemampuan motorik tersebut sangat perlu diketahu olahraga para guru pendidikan jasmani dalam peningkatan kemampuan motorik siswa Sekolah Dasar.

Pada umumnya yang dilaksanakan dalam proses pembelajaran pendidikan jasmani di sekolah dasar merupakan pengembangan dari mototik yang bertujuan untuk mencapai kesegaran jasmani. Oleh karena itu disetiap sekolah harus memiliki data dan dokumentasi tentang tingkat kemampuan motorik siswa sehingga akan memudahkan dan membantu guru pendidikan jasmani dalam memantau kemampuan motorik siswa di sekolah.

Selanjutnya sesuai dengan tujuan penelitian ini maka keterkaitan variabel penelitian nantinya antara kemampuan motorik, dan hasil belajar, kemampuan motorik dengan hasil belajar pendidikan jasmani olahraga dan kesehatan di Sekolah Dasar Negeri 25 Air Tawar Selatan Kecamatan Padang Utara Kota Padang, sangat perlu ditinjau agar proses belajar mengajar pendidikan jasmani olahraga dan kesehatan lebih dapat diarahkan sesuai dengan tujuan pendidikan jasmani di sekolah secara umum dan khususnya pada sekolah dasar.

Dalam hal ini salah satu faktor dilihat tidak adanya rutinitas fisik yang berlebihan seperti; sprint, joging dalam waktu lama, dan masih banyak lagi yang diberikan kepada siswa sekolah dasar untuk meningkat kemampuan motorik siswa sehingga aktivitas belajar diikuti sering mengalami kejenuhan dan rasa malas, sering hal ini tidak terpehatikan sehingga saat ujian akhir siswa sangat banyak tidak mampu untuk mendapat penilai sesuai acuan patakon dalam kompetensi dasar yang diharapkan.

Selanjutnya agar dapat melakukan aktivitas gerak dengan baik dipengaruhi oleh faktor dan komponen kemampuan motorik siswa sehingga aktivitas gerakan yang akan dilakukan dapat diikuti oleh siswa dengan baik dan maksimal sesuai dengan kemampuan gerak tubuhnya. Sehingga Hasil belajar pendidikan jasmani olahraga dan kesehatan juga dapat dicapai dengan baik dan nilai bagus.

Siswa yang segar belum tentu memiliki kemampuan gerak yang relevan untuk dapat melaksanakan aktivitas pembelajaran pendidikan jasmani olahraga dan kesehatan. Karena kemampuan gerak menutut fisik siswa mampu untuk memecahkan beban, rintangan, dan kejenuhan ditinjau secara psikologi. Sehingga hasil belajar diharapkan akan dicapai oleh siswa pendidikan jasmani olahraga dan kesehatan sesuai dengan tujuan pembelajaran pendidikan jasmani olahraga dan kesehatan yang ada dalam kurikulum pendidikan jasmani untuk siswa sekolah dasar khusus SDN 25 Air Tawar Selatan kecamatan padang utara.

Sesuai dengan apa yang telah dikemukakan di atas bahwa dengan tingkat kemampuan motorik yang baik akan dapat membantu seseorang menyelesaikan pekerjaan atau aktivitas yang perlu dilakukan tanpa mengalami kelelahan yang berarti. Oleh karena itu kebugaran bagi setiap orang sangat berarti apalagi siswa, dimana mereka melewati hari demi harinya duduk di bangku sekolah mendengarkan dan mengikuti proses pembelajaran di kelas, di rumah membantu orang tua, dan bermain dengan teman-temannya, serta mengerjakan tugas-tugas membutuhkan kesegaran jasmani yang prima.

Kemampuan motorik adalah kemampuan dasar atau kualitas hasil gerak yang berasal dari dalam maupun luar diri anak untuk mengacu pada keterampilan gerak rendah. Motorik merupakan suatu kebutuhan yang harus dipelajari pada usia sekolah dasar, mengingat hal tersebut sangat dibutuhkan untuk menunjang perkembangan postur tubuh di masa remaja dan dewasa. 
Uraian di atas menegaskan bahwa akibat dari usaha belajar akan menyebabkan terciptanya apa yang disebut dengan hasil belajar. Dengan demikian, hasil belajar adalah produk dari kegiatan belajar yang diikuti oleh seseorang. Hasil belajar yang dicapai tersebut bisa naik dan bisa juga jelek, tergantung dari upaya dan kerja keras yang dilakukan seseorang dalam belajar. Sesuai dengan judul penelitian ini, maka yang akan dilihat adalah hubungan kemampuan motorik terhadap hasil belajar siswa kelas V (lima) putra Sekolah Dasar Negeri Sekolah Dasar Negeri 25 Air Tawar kota Padang.

\section{METODE}

Jenis penelitian ini adalah penelitian korelasional yaitu suatu penelitian yang menetukan tingkat hubungan antara variabel bebas dengan variabel terikat. Adapun hubungan yang akan diteliti adalah variabel bebasnya kemampuan motorik dengan variabel terikatnya adalah hasil belajar siswa Sekolah Dasar Negeri 25 Air Tawar Selatan Kecamatan Padang Utara Kota Padang.

Populasi dalam penelitian adalah seluruh siswa Sekolah Dasar Negeri 25 Air Tawar Kecamatan Padang Utara Kota Padang yang terdaftar pada tahun ajaran 2010/2011 yang berjumlah 132 orang siswa yang terdiri dari 78 orang laki-laki dan 58 orang perempuan mulai dari kelas I sampai dengan kelas VI. Untuk lebih jelasnya dapat dilihat pada Tabel I berikut ini.

Tabel 1.

Populasi Penelitian Hubungan Kemampuan Motorik Dengan Hasil Belajar Siswa Sekolah Dasar

\begin{tabular}{|c|c|c|c|c|}
\hline No & Kelas & Laki-laki & Perempuan & Jumlah \\
\hline 1 & I (satu) & 8 & 7 & 15 \\
\hline 2 & II (dua) & 10 & 12 & 22 \\
\hline 3 & III (tiga) & 12 & 9 & 21 \\
\hline 4 & IV (empat) & 11 & 10 & 21 \\
\hline 5 & V (lima) & 20 & 11 & 31 \\
\hline 6 & VI (enam) & 13 & 9 & 22 \\
\hline Jumlah & & 78 & 58 & 132 \\
\hline
\end{tabular}

Mengingat keterbatasan waktu, tenaga, biaya, serta kemampauan yang dimiliki, maka penelitian ini tidak dilakukan terhadap semua populasi. Adapun yang menjadi sampel dalam penelitian ini yaitu kelas V (lima) putra saja yang berjumlah 20. Sedangkan dengan pertimbangan kelas I s.d. kelas IV belum mengikuti seluruh materi mata pelajaran pendidikan jasmani olahraga dan kesehatan. Sehingga siswa kelas V (lima) yang akan menjadi sampel dalam penelitian ini dan juga dibatasi hanya pada siswa putra. Dengan demikian teknik penarikan sampel dilaksanakan dengan teknik total random sampling.

Selanjutnya hal ini siswa kelas V (lima) putra yang terpilih sebagai sampel telah dianggap memiliki pemahaman gerakan dan mengetahui pelaksanaan komponen kemampuan motorik sehingga siswa dalam melakukan gerakan untuk mendapatkan data secara empiris tidak mengalami kesulitan dan hal lain didasarkan siswa telah mengalami gerakan baik melompat, melempar, dan lain sebagai. Sedangkan siswa putri tidak penelitian ikut sebagai sampel terpilih pada penelitian ini, karena keterbatasan waktu peneliti untuk melakukan penelitian dan kemampuan peneliti dalam melaksanakan penelitian ini nanti nya.

\section{Teknik dan Alat Pengumpul Data}

\section{Tes Kemampuan Motorik Siswa}

Untuk mendapatkan data tentang siswa diperoleh dari guru serta bagian administrasi

Sekolah Dasar Negeri 25 Air Tawar Kecamatan Padang Utara Kota Padang, sedangkan untuk mendapatkan data penelitian ini tentang kemampuan motorik siswa kelas V (lima) dilakukan 
melalui test barrow motor ability menurut Miller dalam Depdiknas (2002:105). Untuk mengukur kemampuan motorik siswa menggunakan tes kemampuan motorik yang terdiri dari tiga butir tes yaitu; 1) Kecepatan (speed), 2) Kelincahan (agility), dan 3) Kekuatan (Power).

a) Test Kecepatan (Speed)

a. Tujuan

Kecepatan (speed) di ukur dengan lari sprint 30 meter, dengan tujuan untuk mengukur kecepatan lari.

b. Pelaksanaan

1. Starts dilakukan dengan starts berdiri

2. Pada aba-aba "Bersedia" testi berdiri dengan salah satu ujung jari kakinya sedekat mungkin dengan garis starts

3. Pada aba-aba "Siap" testi siap untuk berlari

4. Pada aba-aba "ya" testi berlari secepatnya menempuh jarak 30 meter sampai melewati garis finish

5. Bersamaan dengan aba-aba "ya" stop watch dijalankan dan dihentikan pada saat testi mencapai garis finish

6. Setiap testi melakukan 2 kali

b) Kelincahan (agility)

a. Tujuan

Kelincahan dalam test ini dilakukan dengan lari bolak-balik (4x10 m), tujuannya adalah untuk mengukur kelincahan testi delama mengubah arah

b. Pelaksanaan

1. Star dilakukan dengan start berdiri, pada aba-aba "Bersedia" testi berdiri dengan salah satu ujung kaki sedekat mungkin dengan garis start.

2. Pada aba-aba "Siap" diberikan dan testi siap untuk berlari dan aba-aba "Ya" testi segera menuju pada garis Finish batas untuk mengambil dan memindahkan balok pertama lingkaran berada ditempat garis start

3. Kembali lagi menuju gari batas untuk mengambil dan memindahkan balok ke dua kesetengah yang berada di tempat garis start. Untuk lebih jelasnya pelaksanaan tes dapat dilihat pada gambar1.

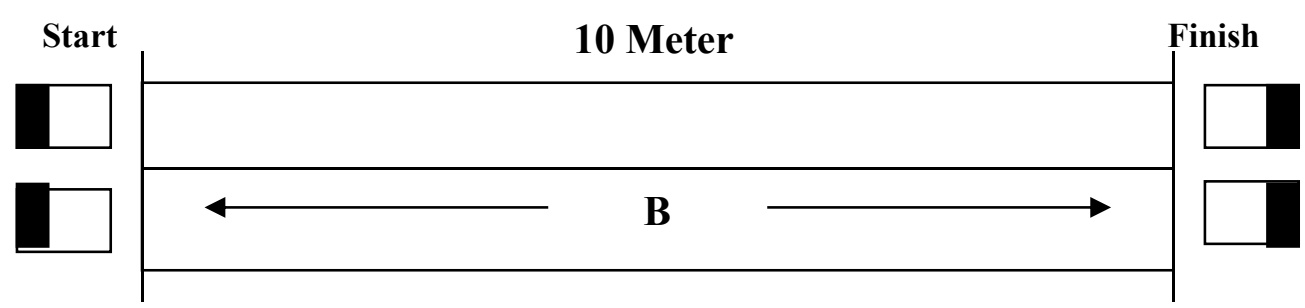

Gambar 1. Lintasan Lari Bolak-balik

Keterangan:

$\begin{array}{ll}\mathrm{A} & = \\ \mathrm{B} & = \\ \mathrm{C}_{1} & = \\ \mathrm{C}_{2} & = \\ \square & = \\ \longrightarrow & = \\ \longleftarrow & =\end{array}$

Garis Start dan Finish

Lintasan Lari

Tempat nalok kayu atau bola

Tempat balok kayu atau bola yang telah dipindahkan

Balok Kayu

Arah Lari pada saat mengambil balok

Arah lari pada saat memindahkan balok 
Sport Science: Jurnal Sain Olahraga dan Pendidikan Jasmani ISSN 114-562X (Cetak), ISSN XXXX-XXXX(Online)

http://sportscience.ppj.unp.ac.id/index.php/jss/index

c) Kekuatan (Power)

a. Tujuan

Kekuatan diukur dengan loncat tegak (vertical jump), tujuan tes ini adalah untuk mengetahui daya ledak otot - otot tungkai

b. Pelaksanaan Test

1. Papan berskala digantung pada dinding setinggi raihan orang yg dites selama melakukan tes tangan testi di taburi serbuk kapur, dan siap berdiri dibawah papan skala menghadap kesamping.

2. Tangan yang akan dipakai menepi papan skala diangkay tinggi-tinggi ke atas dan tempelkan pada papan skala sehingga tangan yang diberi serbuk kapur meninggakan bekas raihan jarinya.

3. Pada skala yang ada pada papan berskala tersebut (titik A) testi mengambil sikap hendak melompat tinggi-tinggi ke atas

4. Testi segera melompat tinggi-tinggi ke atas menepuk papan saat berada dipuncak lompatan bekas tangan ada titik B selisih antara B - A adalah prestasi testi.

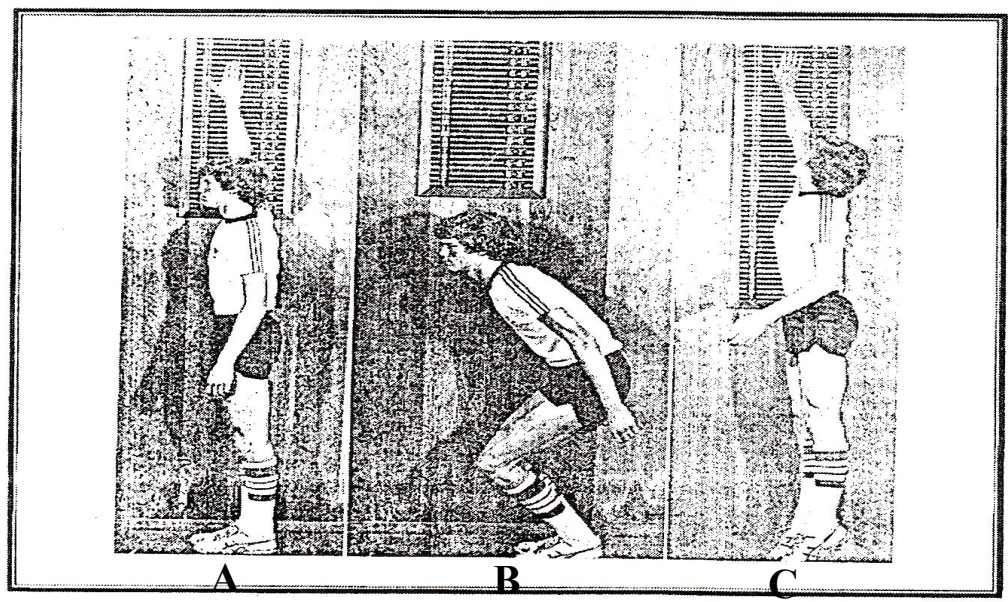

Tabel 2. Instrumen Penelitian Kemampuan Motorik

\begin{tabular}{lll}
\hline No & \multicolumn{1}{c}{ Instrumen } & \multicolumn{1}{c}{ Parameter } \\
\hline 1 & Kecepatan (Lari Cepat 30 meter) & Detik (second) \\
2 & Kelincahan (Lari bolak-balik, 4x10 meter) & Detik (second) \\
3 & Kekuatan (Loncat Tegak) & Detik (second) \\
\hline
\end{tabular}

Sumber: Depdiknas (2002:105)

\section{Hasil Belajar}

Untuk kepentingan data penelitian hasil belajar yang dijadikan sumber data adalah nilai ratarata mata pelajaran pendidikan jasmani olahraga dan kesehatan yang ada dirapor yang diperoleh dari siswa dari hasil belajarnya pada semester genap tahun ajaran 2010/2011, hasil belajar ini mengambarkan penguasaan siswa terhadap pengetahuan, keterampilan maupun sikap yang diperoleh dari kegiatan belajar. Berdasarkan pada hipotesis yang diajukan, analisis data yang dilakukan dengan menggunakan statistik analisis korelasi. Sebelum data dianalisis terlebih dahulu dilakukan uji normalitas dengan uji Liliefors dan uji Linieritas persamaan regresi pada taraf signifikan 0,05.

Analisis korelasi berganda digunakan untuk membuktikan penelitian yang diajukan, adapun rumus korelasi tersebut menggunakan rumus korelasi product moment oleh Pearson dalam Muhidin dan Maman 2007:132. Uji signifikan korelasi menurut Sudjana (1992), dilakukan untuk mengetahui 
apakah yang telah dihitung melalui koefisien itu signifikan atau tidak, maka perlu dilakukan langkah mencari uji signifikan korelasi dengan rumus berikut ini:

$$
t=r_{s} \sqrt{\frac{n-k-1}{1-r_{s}^{2}}}
$$

Keterangan :

$$
\begin{aligned}
& \mathrm{t}=\text { Nilai signifikansi } \\
& \mathrm{n}=\text { Jumlah sampel } \\
& \mathrm{k}=\text { Jumlah variabel bebas } \\
& \mathrm{r}=\text { Koefisien korelasi linear }
\end{aligned}
$$

\section{HASIL DAN PEMBAHASAN}

\section{Hasil Penelitian}

Setelah dilakukan penelitian pada siswa Sekolah Dasar Negeri 25 Air Tawar Kecamatan Padang Utara Kota Padang, maka dapat dideskripsikan data yang didapat seperti pada Tabel berikut ini;

Tabel 3. Deskrispi Data Penelitian Putra

\begin{tabular}{lll}
\hline \multicolumn{1}{c}{ Variabel } & \multicolumn{1}{c}{ Kemampuan Motorik } & \multicolumn{1}{c}{ Hasil Belajar } \\
\hline Nilai tertinggi & 9 & 88 \\
Nilai Terendah & 7 & 66 \\
Rata-rata & 8.25 & 76.85 \\
Simpangan Baku & 0.72 & 6.68 \\
\hline
\end{tabular}

\section{Variabel Kemampuan Motorik}

\section{a. Lari Cepat 30 Meter}

Hasil penelitian menunjukkan rentang kemampuan motorik (X) adalah antara 8.50 detik sampai 6.70 dengan rata-rata 7.56 dan median sebesar 7.50 dan simpangan baku sebesar 0,65.

Selanjutnya distribusi frekuensi dapat dilihat pada table berikut dari data yang telah diberikan skor terhadap hasil tes lari cepat 30 meter adalah sebagai berikut:

Tabel 4. Distribusi Frekuensi Lari Cepat 30 Meter

\begin{tabular}{llll}
\hline \multicolumn{1}{c}{$\begin{array}{c}\text { Kategori } \\
\text { (Nilai) }\end{array}$} & Interval Kelas & \multicolumn{2}{c}{ Frekuensi } \\
Absolute & Relatif (\%) \\
\hline Sangat Baik (5) & s.d -5.50 & 0 & 0 \\
Baik Sekali (4) & $6.60-6.10$ & 0 & 0 \\
Baik (3) & $6.20-6.90$ & 5 & 25 \\
Cukup (2) & $7.00-8.60$ & 15 & 75 \\
Kurang (1) & $8.70-$ dst & 0 & 0 \\
& & 20 & 100 \\
\hline
\end{tabular}

Berdasarkan tabel 4, terlihat testee yang berada pada kategori sangat baik sekali dan baik sekali tidak ada, yang berada di kategori baik sebanyak 5 orang $(25 \%)$, dan testee terbanyak berada pada kategori cukup yaitu sebanyak 15 (75\%). Selanjutnya histogram variabel kemampuan motorik dapat dilihat pada gambar 4.1 di bawah ini : 
Sport Science: Jurnal Sain Olahraga dan Pendidikan Jasmani ISSN 114-562X (Cetak), ISSN XXXX-XXXX(Online)

http://sportscience.ppj.unp.ac.id/index.php/jss/index

Gambar 3. Diagram Histogram Lari Cepat 30 Meter

\section{b. Kelincahan (Lari Bolak-balik 4x10 Meter)}

Hasil penelitian menunjukkan rentang distirbusi frekuensi kelincahan adalah antara 17.90 detik sampai 16.20 dengan rata-rata 16.90 dan median sebesar 16.95 dan simpangan baku sebesar 0,51 .

Selanjutnya distribusi frekuensi dapat dilihat pada table berikut dari data yang telah diberikan skor terhadap hasil tes lari bolak-balik $4 \times 10$ meter adalah sebagai berikut:

Tabel 5. Distribusi Frekuensi Kelincahan

\begin{tabular}{llll}
\hline \multicolumn{1}{c}{$\begin{array}{c}\text { Kategori } \\
\text { (Nilai) }\end{array}$} & \multicolumn{1}{c}{ Interval Kelas } & \multicolumn{2}{c}{ Frekuensi } \\
Absolute & Relatif (\%) \\
\hline Sangat Baik (5) & $13.50-$ Ke atas & 0 & 0 \\
Baik Sekali (4) & $14.00-15.30$ & 0 & 0 \\
Baik (3) & $15.40-16.30$ & 1 & 5 \\
Cukup (2) & $16.40-17.30$ & 16 & 80 \\
Kurang (1) & $17.40-$ dst & 3 & 15 \\
& & 20 & 100 \\
\hline
\end{tabular}

Berdasarkan tabel 4.2, terlihat testee yang berada pada kategori sangat baik sekali dan baik sekali tidak ada, yang berada di kategori baik sebanyak 1 orang $(5 \%)$, dan testee terbanyak berada pada kategori cukup yaitu sebanyak 16 orang $(80 \%)$ sedangkan kategori kurang yaitu sebanyak 3 orang $(15 \%)$. Selanjutnya histogram variabel kelincahan dapat dilihat pada gambar 4.1 di bawah ini :

Grafik Histogram Lari Bolak-balik $4 \times 10$ Meter

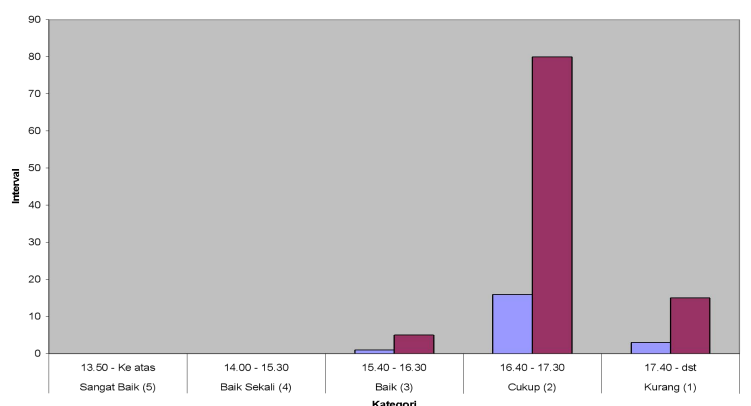

Gambar 4. Diagram Histogram Kelincahan

c. Loncat Tegak

Hasil penelitian menunjukkan rentang loncat tegak adalah antara $29 \mathrm{~cm}$ sampai $38 \mathrm{~cm}$ dengan rata-rata 33.70 dan median sebesar 34.00 dan simpangan baku sebesar 2.79.

Selanjutnya distribusi frekuensi dapat dilihat pada table berikut dari data yang telah diberikan skor terhadap hasil tes loncat tegak adalah sebagai berikut: 


\begin{tabular}{llll}
\hline \multicolumn{3}{c}{ Tabel 6. Distribusi Frekuensi Loncat Tegak } \\
\cline { 2 - 5 } $\begin{array}{c}\text { Kategori } \\
\text { (Nilai) }\end{array}$ & Interval Kelas & \multicolumn{2}{c}{ Frekuensi } \\
& Absolute & Relatif (\%) \\
\hline Sangat Baik (5) & 38 Keatas & 3 & 15 \\
Baik Sekali (4) & $30-37$ & 16 & 80 \\
Baik (3) & $22-29$ & 1 & 5 \\
Cukup (2) & $13-21$ & 0 & 0 \\
Kurang (1) & 12 dst & 0 & 0 \\
& & 20 & 100 \\
\hline
\end{tabular}

Berdasarkan tabel 4.2, terlihat testee yang berada pada kategori sangat baik sebanyak 3 orang $(15 \%)$, yang berada di kategori baik sekali sebanyak 16 orang $(80 \%)$, dan testee berada pada kategori baik sebanyak 1 orang $(5 \%)$ dan kategori cukup dan kategori kurang tidak ada siswa yang berada pada kategori tersebut. Selanjutnya histogram variabel loncat tegak dapat dilihat pada gambar 4.1 di bawah ini :

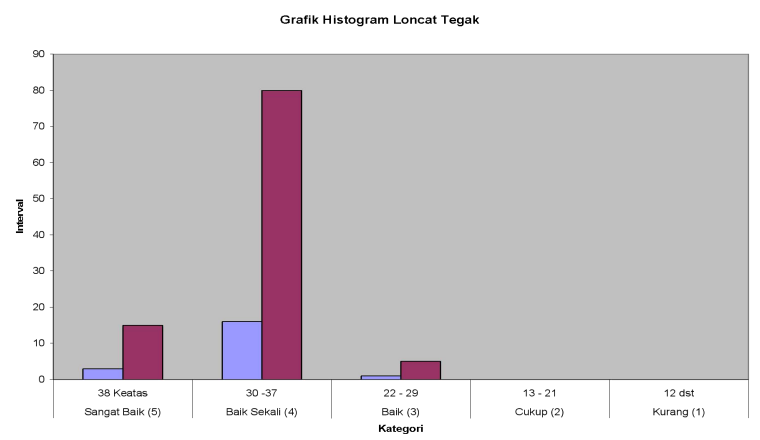

\section{Variabel Hasil Belajar (Y)}

Gambar 5. Diagram Histogram Loncat Tegak

Hasil penelitian menunjukkan rentang hasil belajar siswa (Y) adalah antara 66 sampai 88 dengan rata-rata 76.85 dan median 75.00 dengan simpangan baku sebesar 6.68. Distribusi frekuensi dapat dilihat pada table 7 berikut:

Tabel 7 Distribusi Frekuensi Belajar

\begin{tabular}{llll}
\hline $\begin{array}{c}\text { Kategori } \\
\text { (Nilai) }\end{array}$ & Interval Kelas & & \multicolumn{2}{c}{ Frekuensi } \\
Absolute & Relatif (\%) \\
\hline Sangat Baik & $>95$ & 0 & 0 \\
Baik Sekali & $80-94$ & 7 & 35 \\
Baik & $65-79$ & 13 & 65 \\
Cukup & $55-64$ & 0 & 0 \\
Kurang & $<54$ & 0 & 0 \\
& & 20 & 100 \\
\hline
\end{tabular}

Berdasarkan tabel diatas, dibandingkan dengan nilai rata-rata, terlihat testee yang berada pada nilai baik sekali sebanyak 7 orang (35\%) dan yang berada di kategori nilai baik 13 orang $(65 \%)$. Selanjutnya histogram variabel hasil belajar dapat dilihat pada gambar di bawah ini : 


\section{Pengujian Persyaratan Analisis}

\section{Gambar 6. Grafik Histogram Hasil Belajar}

Hipotesis pada penelitian ini di uji dengan menggunakan analisis korelasi product moment dan dilanjutkan uji t untuk koefisien korelasi. Untuk menggunakan teknik ini ada beberapa persyaratan yang harus dipenuhi diantaranya ;

\section{Uji Homogenitas}

Pengujian hoomogenitas variable kemampuan motorik (X) dan hasil belajar (Y) dengan Ho jika Lo $<$ Lt maka data berdistribusi homogen, dan Ha jika Lo $>$ Lt maka data tidak homogen. Dari analisis terlihat bahwa variable kemampuan motorik pada penelitian putra berdistribusi homogen $\left(\right.$ Lo $\left.>\mathrm{L}_{\text {tabel, }}\right)$, maka uji statistik yag berikutnya digunakan adalah statistik non parametrik, dimana dalam hal ini pembuktian hipotesis penelitian dilakukan dengan analisis korelasi spearman.

\section{Pengujian Hipotesis}

Untuk menguji hipotesis ini dilakukan analisa korelasi antara variable $\mathrm{X}$ dengan variable $\mathrm{Y}$, dengan hipotesa analisa korelasinya adalah sebagai berikut:

Ho $=$ Tidak terdapat hubungan yang signifikan antara kemampuan motorik dengan hasil belajar penjasorkes

$\mathrm{Ha}=$ Terdapat hubungan yang signifikan antara kemampuan motorik dengan hasil belajar penjasorkes berikut:

Dari analisa korelasi yang dilanjutkan dengan uji t didapatkanlah hasil seperti pada table

Tabel 8. Hasil Analisa Korelasi Kemampuan Motorik (X) dengan Hasil Belajar (Y)

\begin{tabular}{|c|c|c|c|c|c|}
\hline Sampel & Hubungan & $\begin{array}{l}\text { Lamba } \\
\text { ng }\end{array}$ & $\begin{array}{l}\text { Nilai koefisien } \\
\text { korelasi }\end{array}$ & $\begin{array}{c}\text { Uji keberartian } \\
\text { Koef. Korelasi }\end{array}$ & $\begin{array}{l}\text { Nilai Kritis Pada } \\
\text { Tabel } \alpha 5 \%\end{array}$ \\
\hline Putra Kelas V & $\begin{array}{lr}\text { Hubungan } & \text { antara } \\
\text { Kemampuan Motorik (X) } \\
\text { dengan Hasil Belajar } \\
\text { Penjasorkes (Y) }\end{array}$ & $r_{x y}$ & 4.835 & $t_{\text {hitung }}=4.835^{*}$ & $\mathrm{t}_{\text {tabel }}=1.72$ \\
\hline
\end{tabular}

Dengan melihat tabel distribusi $\mathrm{t}$ dengan $\mathrm{dk}=\mathrm{n}-23$, diperoleh nilai tabel 1.72 , yaitu dari $1-\alpha$ atau 0.95 sebagai dk pembilang dan $n-2$ (21) sebagai dk penyebut. Kriteria pengujian adalah jika $t_{\text {thitung }}>\mathrm{t}_{\text {tabel }}, \mathrm{H}_{\mathrm{o}}$ yang menyatakan tidak terdapat hubungan antara table yang di tolak. Sebaliknya jika $\mathrm{t}_{\text {hitung }}<\mathrm{t}_{\text {tabel }}$ Ho diterima

Oleh karena itu thitung $(4,835)>t_{\text {tabel }}(1.72)$ maka Ho di tolak dan Ha diterima

Dengan demikain dapat disimpulkan bahwa terdapat hubungan yang signifikan antara variable bebas dengan variable terikat. Dengan kata lain terdapat hubungan yang berarti antara Kemampuan motorik dengan Hasil belajar dan konsekuensinya Ha diterima.

\section{Pembahasan}

Berdasarkan temuan penelitian tentang kemampuan motorik dan hasil belajar yang melihat hubungan antara dua variabel ini, sehingga peneliti sangat banyak mendapat pengalaman berarti dalam sebuah penelitian dilakukan tersebut. Melihat kemampuan motorik siswa kelas V Putra SDN 25 Air Tawar Selatan Kec. Padang Utara Kota Padang yang baik akan dapat membantu penilaian hasil belajar penjasorkes. 
Selanjutnya masalah dalam penelitian yang telah diajukan yaitu; (1) Kualitas gerakan yang ditampilkan siswa belum sesuai dengan fase gerak dasar sehingga gerakan yang dilakukan memiliki kualitas yang rendah tidak sesuai dengan penilaian dalam hasil belajar penjasorkes menurut sistem penilai pendidikan penjas, (2) Aktivitas gerakan tidak bersemangat dalam artian siswa tidak bebas dalam bergerak, dan (3) Kondisi dan situasi dalam proses belajar mengajar terbatas seperti; lampangan yang sempit, sarana prasaran tidak memadai, dan terlalu banyak modifikasi dan ilustrasi gerak diberikan agar siswa dapat mengetahui, sehingga memerlukan waktu yang lama.

Memberikan dorongan kepada peneliti untuk membuktikannya dalam bentuk data secara empiris, dari pemahaman peneliti sendiri dan bimbingan Penasehat Akademik peneliti membatasi hanya melihat hubungan antara kemampuan motorik dan hasil belajar siswa kelas V putra saja. Sesungguhnya sangat banyak variable yang bisa diteliti secara umum, namun karena keterbatas peneliti dan waktu dalam melakukan penelitian nantinya maka peneliti membatasi hanya pada variable tersebut diatas.

Sedangkan tujuan penelitian ini yaitu; Mengetahui seberapa besar hubungan kemampuan motorik terhadap hasil belajar Sekolah Dasar Negeri 25 Air Tawar Selatan. Dan ingin mengetahui sejauhmana hubungan kemampuan motorik terhadap hasil belajar pendidikan jasmani olahraga dan kesehatan.

Dengan melihat tabel distribusi $\mathrm{t}$ dengan $\mathrm{dk}=\mathrm{n}-23$, diperoleh nilai $\mathrm{t}_{\text {tabel }} 1.72$, yaitu dari $1-\alpha$ atau 0.95 sebagai $\mathrm{dk}$ pembilang dan $\mathrm{n}-2$ (21) sebagai $\mathrm{dk}$ penyebut. Kriteria pengujian adalah jika $t_{\text {hitung }}>\mathrm{t}_{\text {tabel }}, \mathrm{H}_{\mathrm{o}}$ yang menyatakan tidak terdapat hubungan antara table yang di tolak. Sebaliknya jika $t_{\text {hitung }}<t_{\text {tabel }}$ Ho diterima. Oleh karena itu thitung $(4,835)>t_{\text {tabel }}(1.72)$ maka Ho di tolak dan Ha diterima.

Dengan demikain dapat disimpulkan bahwa terdapat hubungan yang signifikan antara variable bebas dengan variable terikat. Dengan kata lain terdapat hubungan yang berarti antara Kemampuan motorik dengan Hasil belajar dan konsekuensinya Ha diterima. Berdasarkan hasil temuan dilapangan tersebut diatas memang sangat relevan antara kemampuan motorik dan hasil belajar penjasorkes untuk diteliti. Karena kemampuan motorik adalah kemampuan dasar atau kualitas hasil gerak yang berasal dari dalam maupun luar diri anak untuk mengacu pada keterampilan gerak.

Motorik merupakan suatu kebutuhan yang harus dipelajari pada usia sekolah dasar, mengingat hal tersebut sangat dibutuhkan untuk menunjang perkembangan postur tubuh di masa remaja dan dewasa. Sedangkan fungsi kemampuan motorik untuk mengembangkan kesanggupan dan kemampuan setiap individu yang berguna untuk mempertinggi daya kerja. Dengan landasan untuk menguasai tugas keterampilan motorik yang khusus. Sedangkan kemampuan seseorang untuk dapat menguasai keterampilan-keterampilan motorik olahraga berbeda-beda, perbedaan tersebut ditentukan oleh: kemampuan kondisi dan koordinasi yang dimiliki, perbedaan usia, pengalaman gerakan, jenis kelamin, frekuensi latihan, perbedaan tujuan dan motivasi dalam mempelajari suatu keterampilan motorik serta perbedaan suatu kemampuan kognitif".

Maka peneliti dapat menyimpulkan akibat dari usaha belajar akan menyebabkan terciptanya apa yang disebut dengan hasil belajar. Dengan demikian, hasil belajar adalah produk dari kegiatan belajar yang diikuti oleh seseorang. Hasil belajar yang dicapai tersebut bisa naik dan bisa juga jelek, tergantung dari upaya dan kerja keras yang dilakukan seseorang dalam belajar.

\section{KESIMPULAN}

Berdasarkan analisis data dari penelitian hubungan kemampuan motorik dengan hasil belajar siswa putra kelas V Sekolah Dasar Negeri 25 Air Tawar Kecamatan Padang Utara Kota Padang. Dari hasil analisa data terhadap koefiesien korelasi maka berdasarkan tabel distribusi $t$ dengan $\mathrm{dk}=\mathrm{n}-23$, diperoleh nilai tabel 1.72 , yaitu dari $1-\alpha$ atau 0.95 sebagai dk pembilang dan $\mathrm{n}-2$ (21) sebagai $\mathrm{dk}$ penyebut. Kriteria pengujian adalah jika $t_{\text {hitung }}>t_{\text {tabel }}, H_{o}$ yang menyatakan tidak terdapat hubungan antara table yang di tolak. Sebaliknya jika $t_{\text {hitung }}<t_{\text {tabel }}$ Ho diterima. Oleh karena itu $t_{\text {hitung }}(4,835)>t_{\text {tabel }}$ (1.72) maka Ho di tolak dan Ha diterima. 
Sport Science: Jurnal Sain Olahraga dan Pendidikan Jasmani ISSN 114-562X (Cetak), ISSN XXXX-XXXX(Online)

http://sportscience.ppj.unp.ac.id/index.php/jss/index

Dengan demikain dapat disimpulkan bahwa terdapat hubungan yang signifikan antara variable bebas dengan variable terikat. Dengan kata lain terdapat hubungan yang berarti antara Kemampuan motorik dengan Hasil belajar dan konsekuensinya Ha diterima. Kepada siswa putra Sekolah Dasar Negeri 25 Air Tawar Kecamatan Padang Utara Kota Padang agar bisa memahami instrusional materi pembelajaran yang disampaikan oleh guru guna mendapatkan hasil belajar yang lebih baik lagi.

Bagi pembina kegiatan ekstrakurikuler agar lebih mengembangkan dan mengarahkan aktivitas gerak yang dilakukan oleh siswa kea arah pengembangan kemampuan motorik di Sekolah Dasar Negeri 25 Air Tawar Kecamatan Padang Utara Kota Padang agar membuat program pembelajaran yang sesuai dengan keadaan siswa baik secara fisik ataupun sosial Diharapkan kepada peneliti lain agar dapat melanjutkan penelitian ini, dengan melihat variabel-variabel lainnya yang berhubungan dengan tingkat kemampuan motorik.

Sebagai pedoman bagi siswa Sekolah Dasar Negeri 25 Air Tawar Kecamatan Padang Utara Kota Padang, dalam pembelajaran pendidikan jasmani olahraga dan kesehatan. Hasil penelitian sebagai modal dasar dalam melihat kekuarang siswa dalam mengikuti proses pembelajaran pendidikan jasmani olahraga dan kesehatan baik di kota padang secara khusus atau secara nasional secara umumnya.

\section{DAFTAR RUJUKAN}

Ahady, Muchtar, Hairy, Junusul. 1982. Kesegaran Jasmani. Padang; FPOK IKIP Padang.

Asril. 1999. Pembinaan Kondisi Fisik, Padang FIK UNP.

Bompa TO. 1983. Theory and Methodologi of Training: The key to atletic performance $2^{\text {nd }}$ edition, lowa: Kendal/Hunt Pub. Company.

Cooper, Kenneth. 1982. Aerobic. Jakarta; PT. Gramedia.

Depdikbud. 1993. Psikologi Pendidikan, Jakarta: Depdikbud.

Depdiknas. 1993. Undang-undang Sistem Pendidikan Nasional. Jakarta: BP Cipta Jaya.

Depdiknas, 2002. Dasar-dasar Kepelatihan OLahraga. Jakarta: Proyek Pendidikan Jasmani Luar Biasa Gusril, 2003. Fakto-faktor Yang mempengaruhi Kemampuan Motorik Siswa Sekolah Dasar Negeri

Kodya Padang. Disertasi. Jakarta: Pascasarjana, Universitas Negeri Jakarta

Kiram, Yanuar. 1992. Belajar Motorik. Jakarta: Depdikbud

Kiram, Yanuar. 2000. Belajar Motorik. Padang: FIK Universitas Negeri Padang

Lutan, Rusli. 2000. Strategi Belajar Mengajar Penjaskes, Jakarta: Depdikbud.

Lutan Rusli. 2001. Asas-asas Pendidikan Jasmani, Jakarta: Dirjen OR.

Miller, K David, 2002. Measurment By The Phsycal Educator Why and How. New York: Mc Graw Hill Higher Education

Slameto. 1995. Belajar dan Faktor-faktor yang mempengaruhi. Jakarta; PT. Rineka Cipta.

Sudarno. 1992. Pendidikan Kesegaran Jasmani. Depdikbud; Jakarta

Sudjana. 1992. Teknik Regresi dan Korelasi. Bandung; Tarsito.

Sukmadinata. 2003. Landasan Psikologi Proses Pendidikan. Bandung; PT. Remaja Rosada Karya.

Setyo, Nugroho. 2005. Status Kemampuan Motorik Umum Siswa Sekola Sepak Bola di Kabupaten

Sleman. Yogyakarta. FIK Universitas Negeri Yogyakarta.

Sukadiyanto. 2002. Teori dan Metodologi Melatih Fisik Petenis. Yogyakarta: Universitas Negeri Yogyakarta.

Sukintaka, 2001. Teori Pendidikan Jasmani: Filosofi Pembelajaran dan Masa Depan. Badung: Nuansa. Sukintaka, 2004. Teori Pendidikan Jasmani: Filosofi Pembelajaran dan Masa depan. Bandung: Nuansa. 